\title{
The Chronically Reserpinized Rat as an Animal Model for Cystic Fibrosis: I. Acute Effect of Isoproterenol and Pilocarpine upon Pulmonary Lavage Fluid
}

\author{
THOMAS P. MAWHINNEY, MILTON S. FEATHER, J. RICARDO MARTINEZ, AND GIULIO J. \\ BARBERO \\ Departments of Biochemistry and Child Health, University of Missouri Medical Center, Columbia, Missouri, USA
}

\begin{abstract}
Summary
Lung lavage samples from rats treated in a chronic fashion with reserpine had mean increases of 133,170 , and $120 \%$ in the total protein, lipid, and carbohydrate contents, respectively, when compared with those of untreated control animals, when these values were expressed in terms of body weight. An acute single ip injection of the $\beta$-adrenergic agent isoproterenol $(10 \mathrm{mg})$ increased the glycoprotein content of pulmonary lavage fluid from control rats approximately $15-19 \%$, but only $9-10 \%$ in those from reserpine treated rats. By contrast, pilocarpine $(10 \mathrm{mg})$, administered in the same manner, caused a $15 \%$ increase in the total protein, carbohydrate, and lipid content of lavage samples from control rats and increased these same constituents in the lavage samples of reserpine treated rats 98,102 , and $80 \%$, respectively. The increased total carbohydrate content in the lavage samples of the treated animals was not associated with changes in the percent distribution of neutral sugars, amino sugars, or sialic acid. The ratio of these various sugar components did not change in the lavage samples of control or reserpine treated rats upon stimulation with either pilocarpine or isoproterenol. The increased total lipid content fround in the lavage samples from the treated rats probably results from an increase in phospholipids. A decrease in phospholipid content occurred in the lavage samples of reserpine treated rats upon stimulation, while the opposite was observed in those of control animals. Chronic treatment of rats with reserpine, thus, appears to induce an enhanced production of glycoproteins in the airways and to interfere with phospholipid metabolism in the lung. In addition, the drug treatment enhances the secretory response to pilocarpine in comparison with the responses of control animals. The enhanced response or hypersecretion of glycoproteins is a quantitative one and does not seem to involve alterations in the ratios or distribution of the various sugar components. This disturbance in the secretory function of the respiratory tract, a target organ which is prominently involved in cystic fibrosis (CF) together with alterations in other exocrine glands which resemble those of CF patients, makes the reserpine treated rat a useful model for the further study of possible pathogenetic mechanisms in $\mathbf{C F}$.
\end{abstract}

\section{Speculation}

The experimental animal model for $\mathrm{CF}$ developed by the chronic administration of reserpine to rats has been found to have changes in the protein content of lung lavage samples, in addition to morphologic and secretory alterations in the salivary glands and the pancreas. Further analysis of the organic composition of lung lavage samples shows that the protein, carbohydrate, and lipid contents are significantly increased after chronic reserpine administration and that the response to stimulation with pilocarpine is enhanced in the treated animals when compared to that of untreated control rats. It therefore appears that chronic reserpine administration causes a hypersecretion of glycoproteins and changes in lipid metabolism in the respiratory tract of the rat and that, in conjunction with previous findings in other exocrine glands, these effects on lung function make the reserpine treated rat a useful tool for the study of the pathologic disturbance seen in the major exocrine glands affected in CF.

An animal model for CF developed by the chronic administration of reserpine to rats shows not only morphologic and secretory changes in the salivary glands $(16,17,18,19)$ and pancreas $(20)$, but also alterations in the protein content of pulmonary lavage fluids, involving a significant increase in the total protein content and in the absolute and relative amounts of a low molecular weight glycoprotein, which were also observed in lung lavage samples from patients with CF (28).

Hypersecretion of mucous in the airways is a prominent feature of CF (7) and several lines of evidence have indicated that there may be alterations in the organic and inorganic composition of CF pulmonary fluids $(3,6,22)$. The reasons for the hypersecretion of mucus in the respiratory tree and in other exocrine glands of the CF patient are unknown and several hypotheses have been proposed to explain it, including the suggestion that it may result from a disturbance in the neurohumoral regulation of exocrine glands (4). Because pulmonary secretions are also regulated, at least in part, by the autonomic nervous system $(5,26)$, it became of interest to investigate the pulmonary secretions of the animal model after stimulation with autonomic agents. In this investigation, we have expanded, therefore, our previous observations on the protein content of unstimulated pulmonary secretions by analyzing the organic composition of pulmonary lavage samples after acute stimulation with pilocarpine and with isoproterenol. An analysis of the total protein, the carbohydrates, and the lipids of lavage fluids from reserpine treated rats was performed in the resting and stimulated conditions. The results were compared to those obtained in paired experiments on untreated control animals.

\section{METHODS AND MATERIALS}

\section{PREPARATION OF ANIMALS AND COLLECTION OF LAVAGE SAMPLES}

Thirty-eight adult male Sprague-Dawley rats (150-200 g) were treated with daily ip injections of reserpine $(0.5 \mathrm{mg} / \mathrm{kg}$ body weight) for 7 days. Thirty-four rats, which received either no injection or a daily saline injection for 7 days were designated as controls. Twenty-four hr after the last injection, a specified num- 
ber of reserpine-treated and control rats were anesthetized with 8 $\mathrm{mg} / 100 \mathrm{~g}$ body weight of sodium pentobarbital and the tracheas were exposed by a midline neck incision and cannulated. The lungs were lavaged with two $12 \mathrm{ml}$ volumes of sterile saline. In other experiments, both control and reserpine-treated rats were also anesthetized on the 8 th day and received a $10 \mathrm{mg}$ ip injection of either pilocarpine nitrate or isoproterenol sulfate. The lung lavage procedure indicated above was then performed $10 \mathrm{~min}$ later. This time period was selected in order to assess the shortterm effects of the two secretagogues, because they have a clear cut effect in eliciting other exocrine secretions a few minutes after their administration to rats. Samples containing red blood cells or hemolytic products were discarded.

\section{CHEMICAL ANALYSIS OF PULMONARY LAVAGE SAMPLES}

Pooled saline lavages of each rat were centrifuged at $3000 \mathrm{rpm}$ for $30 \mathrm{~min}$ at $4^{\circ} \mathrm{C}$ to remove cellular and insoluble material. The supernatant was carefully aspirated without pellet disturbance and dialyzed for $24 \mathrm{hr}$ against 50 volumes of distilled water containing $0.001 \%$ ethylenediaminetetraacetate. Aliquots of lavage samples before and after centrifugation and after dialysis were analyzed for protein (14) and carbohydrate (8) content. The dialysates were flash evaporated, lyophilized, weighed, and then delipidated with $\mathrm{N}$-butanol:acetone (1:1) and ether:chloroform:methanol (1:2:1). Organic solvents were pooled for each lavage sample, dried under nitrogen, and the lipids weighed. Separation of lipids into neutral lipid, glycolipid, and phospholipid fractions was achieved by silica gel chromatography (24). Eluted lipids were dried under nitrogen and weighed. Thin layer chromatographic procedures were employed for the separation of neutral (29) and phospholipid (21) subclasses which were visualized by iodine vapor and the spots scraped from the plates. Esterified and free cholesterol were assayed by the direct Lieberman-Burchard reaction (10). Phospholipid phosphorus was quantified by the procedure of Lowry et al. (15).

Delipidated lavage proteins were dissolved in $3.0 \mathrm{ml}$ distilled water and a portion assayed for total protein and carbohydrate. For neutral sugar analysis, a similar aliquot was hydrolyzed in $0.6 \mathrm{~N} \mathrm{HCl}$ at $100^{\circ} \mathrm{C}$ for $4 \mathrm{hr}$ and eluted in sequence through 0.8 $\times 8 \mathrm{~cm}$ columns of Dowex $1-4 \times\left(\mathrm{CO}_{3}=\right.$ form, $\left.50-100 \mathrm{mesh}\right)$ and Dowex 50-8x ( $\mathrm{H}^{+}$form, 200-400 mesh) with distilled water to remove amino acids, peptides, and acid. Neutral monosaccharides (effluent) were dried in $3.0 \mathrm{ml}$ teflon capped vials and derivatized to their corresponding aldononitrile acetates according to the procedure of Varma et al. (31). Analysis of aldononitrile acetate derivatives was performed on a Varian 2400 gas chromatograph equipped with a $3 \%$ OV-225/2.50\% tetramethylcyclobutanediol succinate, $80 / 100$ mesh Supelcoport, column programmed from $175-225^{\circ} \mathrm{C}$ at $4^{\circ} \mathrm{C} / \mathrm{min}$. Isolation and quantification of total hexosamine was performed by the procedure of Boas et al. (1). Sialic acid, liberated by hydrolysis in $0.05 \mathrm{M} \mathrm{H}_{2} \mathrm{SO}_{4}$ at $80^{\circ} \mathrm{C}$ for 1 $\mathrm{hr}$, was determined by a thiobarbituric acid assay (32).

\section{RESULTS}

Expressed in terms of animal body weight, the pulmonary lavage fluid of reserpine treated rats demonstrated mean increases in the total protein, lipid, and carbohydrate contents of 133, 170, and $120 \%$, respectively, when compared to the values for control animals. These differences were statistically significant (Table 1). The mean protein and carbohydrate content of pulmonary lavage samples were elevated approximately $15-19 \%$ in control rats after the acute administration of the $\beta$-adrenergic agent isoproterenol and $9-10 \%$ in reserpine-treated animals. In contrast, pilocarpine increased the total protein, lipid, and carbohydrate contents of control lavage samples an average of $15 \%$ and increased these same constituents in the lavage samples of reserpine animals 98 , 102 , and $80 \%$, respectively. These increases were significantly larger than those observed in control rats (Table 1).

Lavage lipid analyses demonstrated that, when compared to controls, chronic treatment with reserpine decreased neutral lipids $34 \%$ and increased the phospholipid content $42 \%$. Tables 2 and 3 indicate that pilocarpine and isoproterenol had varying effects upon lavage lipid composition. Pilocarpine decreased esterified and free cholesterol and increased phospholipids in controls, while it increased neutral lipid and free cholesterol and decreased the

Table 1. Protein, lipid, and carbohydrate composition of rat lung lavage $e^{1}$

\begin{tabular}{|c|c|c|c|c|}
\hline Group & $n^{2}$ & & Total & $\mu \mathrm{g} / \mu$ body wt \\
\hline Control & 13 & $\begin{array}{l}\text { Protein } \\
\text { Lipid } \\
\text { Carbohy- } \\
\quad \text { drate }\end{array}$ & $\begin{array}{l}1.08 \mathrm{mg}(0.06) \\
1.04 \mathrm{mg}(0.04) \\
59.5 \mu \mathrm{g}(4.5)\end{array}$ & $\begin{array}{l}3.95(0.34) \\
3.80(0.27) \\
0.20(0.01)\end{array}$ \\
\hline Reserpine & 17 & $\begin{array}{l}\text { Protein } \\
\text { Lipid } \\
\text { Carbohy- } \\
\quad \text { drate }\end{array}$ & $\begin{array}{c}1.49 \mathrm{mg}(0.18)^{3} \\
1.66 \mathrm{mg}(0.10)^{3} \\
75.0 \mu \mathrm{g}(9.1)^{3}\end{array}$ & $\begin{array}{r}9.21(1.12)^{4} \\
10.25(0.55)^{4} \\
0.44(0.05)^{4}\end{array}$ \\
\hline $\begin{array}{l}\text { Pilocarpine } \\
\text { Control }\end{array}$ & 11 & $\begin{array}{l}\text { Protein } \\
\text { Lipid } \\
\text { Carbohy- } \\
\quad \text { drate }\end{array}$ & $\begin{array}{l}1.19 \mathrm{mg}(0.12) \\
1.16 \mathrm{mg}(0.06) \\
65.8 \mu \mathrm{g}(6.9)\end{array}$ & $\begin{array}{l}4.50(0.54) \\
4.39(0.34) \\
0.23(0.02)\end{array}$ \\
\hline $\begin{array}{l}\text { Pilocarpine } \\
\text { Reserpine }\end{array}$ & 9 & $\begin{array}{l}\text { Protein } \\
\text { Lipid } \\
\text { Carbohy- } \\
\quad \text { drate }\end{array}$ & $\begin{array}{r}3.08 \mathrm{mg}(0.71)^{4} \\
3.48 \mathrm{mg}(0.41)^{4} \\
139.0 \mu \mathrm{g}(3.1)^{4}\end{array}$ & $\begin{array}{r}18.30(4.70)^{4} \\
20.67(1.20)^{4} \\
0.82(0.20)^{4}\end{array}$ \\
\hline $\begin{array}{l}\text { Isoprotere- } \\
\text { nol } \\
\text { Control }\end{array}$ & 10 & $\begin{array}{l}\text { Protein } \\
\text { Lipid } \\
\text { Carbohy- } \\
\quad \text { drate }\end{array}$ & $\begin{array}{l}1.30 \mathrm{mg}(0.22) \\
1.22 \mathrm{mg}(0.09) \\
63.8 \mu \mathrm{g}(0.11)\end{array}$ & $\begin{array}{l}4.71(0.91) \\
4.42(0.63) \\
0.23(0.04)\end{array}$ \\
\hline $\begin{array}{l}\text { Isoprotere- } \\
\text { nol } \\
\text { Reserpine }\end{array}$ & 12 & $\begin{array}{l}\text { Protein } \\
\text { Lipid } \\
\text { Carbohy- } \\
\quad \text { drate }\end{array}$ & $\begin{array}{c}1.77 \mathrm{mg}(0.37) \\
2.02 \mathrm{mg}(0.21) \\
79.9 \mu \mathrm{g}(1.7)\end{array}$ & $\begin{array}{r}10.12(2.24) \\
11.56(1.01) \\
0.47(0.11)\end{array}$ \\
\hline
\end{tabular}

\footnotetext{
${ }^{1}$ Data expressed as mean \pm SD.

${ }^{2} \mathrm{~N}$, number of animals.

${ }^{3}$ Significance of $P<0.05$, by student $t$ test, when compared to control values.

'Significance of $P<0.05$, by Student $t$ test, when compared to control values.
}

Table 2. Composition of lavage lipid ${ }^{1}$

\begin{tabular}{lccccc}
\hline \multicolumn{1}{c}{ Group } & $\mathrm{N}^{2}$ & Neutral lipid & $\begin{array}{c}\text { Esterified } \\
\text { cholesterol }\end{array}$ & $\begin{array}{c}\text { Free choles- } \\
\text { terol }\end{array}$ & $\begin{array}{c}\text { Phospho- } \\
\text { lipid }\end{array}$ \\
\hline Control & 13 & $31.1(1.0)$ & $14.8(2.3)$ & $8.2(1.7)$ & $41.9(2.5)$ \\
& & & & & \\
Reserpine & 17 & $20.4(2.1)^{3}$ & $16.2(3.4)$ & $2.2(0.8)$ & $59.6(1.9)^{4}$ \\
$\begin{array}{l}\text { Pilo, control } \\
11\end{array}$ & $34.2(2.6)$ & $9.6(2.0)$ & $4.1(1.6)$ & $49.2(3.4)$ \\
$\begin{array}{l}\text { Pilo, reser- } \\
\text { pine }\end{array}$ & 9 & $30.8(1.6)$ & $10.0(2.4)$ & $5.6(2.1)$ & $53.6(3.5)$ \\
$\begin{array}{l}\text { IPR, control } \\
\begin{array}{l}\text { IPR, reser- } \\
\text { pine }\end{array}\end{array}$ & 10 & $25.0(3.4)$ & $13.4(3.7)$ & $9.1(1.6)$ & $46.5(3.1)$ \\
\end{tabular}

${ }^{1}$ Data expresses as percent of total lavage lipid \pm SD.

${ }^{2} \mathbf{N}=$ number of animals.

${ }^{3}$ Significance of $P<0.05$, by student $t$ test, when compared to unstimulated control values.

' Significance of $P<0.001$, by student $t$ test, when compared to unstimulated control values. 
phospholipid content in reserpine rat lavage. Isoproterenol decreased neutral lipid and increased the phospholipid content in control samples and decreased the phospholipid and increased the free cholesterol content of lavage samples from reserpine treated rats. Analysis of individual phospholipids (Table 3) demonstrated slight variation in the two groups of animals in lavage content of phosphatidyl ethanolamine, phosphatidyl serine, and phosphatidyl inositol. Although an average increase of $18 \%$ was found in the phosphatidyl choline content of lavage samples from reserpine-treated animals, the change was not statistically significant. An acute injection of pilocarpine caused a further increase in the phosphatidyl choline content of lavage samples from reserpinetreated rats. In contrast, isoproterenol appeared to reverse the effect of reserpine by decreasing phosphatidyl choline values to control levels.

Gas-liquid chromatographic analysis of protein bound sugars indicated that lavage protein contained a mean of $5.07 \%$ carbohydrate in all samples. Fucose, mannose, galactose, sialic acid, and amino-sugars were identified in a consistent percent ratio of $6.3: 29.1: 23.4: 8.5: 30.5$, respectively, of total carbohydrate composition (Table 4). No significant difference in the percent distribution of carbohydrate components were found in lavage samples from control and from reserpine-treated rats. Free glucose was also present in lavage fluid, but this was removed during dialysis.

\section{DISCUSSION}

Our results demonstrate that the chronic administration of reserpine to rats results in alterations of the organic composition of pulmonary secretions, involving significant increases in the total protein, carbohydrate, and lipid contents of lavage samples obtained in the absence of stimulation. In addition, the response to stimulation with pilocarpine is enhanced in the treated animals, in terms of the secretion of these organic components, when

Table 3. Phospholipid analysis of lavage ${ }^{1}$

\begin{tabular}{lccccc}
\hline \multicolumn{1}{c}{ Group } & $N$ & PE & PS & PI & PC \\
\hline Control & 13 & 7.6 & 4.4 & 1.1 & 62.3 \\
Reserpine & 17 & 8.9 & 2.3 & & 73.3 \\
Pilo, control & 11 & 9.3 & 3.3 & 1.2 & 59.3 \\
Pilo, reserpine & 9 & 10.0 & 1.8 & & 81.0 \\
IPR, control & 10 & 6.5 & 4.1 & 2.1 & 65.5 \\
IPR, reserpine & 12 & 8.5 & 3.6 & 1.5 & 58.6 \\
\hline
\end{tabular}

'Data expressed as percent of total phospholipid, Abbreviations: $N$, number of animals; PE, phosphatidyl ethanolamine; PS, phosphatidyl serine; PI, phosphatidyl inositol; PC, phosphatidyl choline.

Table 4. Carbohydrate composition of rat lung lavage $e^{1}$

\begin{tabular}{lccccc}
\hline & Fucose & $\begin{array}{c}\text { Man- } \\
\text { nose }\end{array}$ & $\begin{array}{c}\text { Galac- } \\
\text { tose }\end{array}$ & $\begin{array}{c}\text { Sialic } \\
\text { acid }\end{array}$ & $\begin{array}{c}\text { Amino } \\
\text { sugar }\end{array}$ \\
\hline Control & 6.05 & 30.02 & 23.19 & 8.36 & 30.74 \\
Reserpine & 6.27 & 28.71 & 23.95 & 8.55 & 29.79 \\
Pilocarpine, control & 6.27 & 28.60 & 21.80 & 8.60 & 30.42 \\
$\begin{array}{l}\text { Pilocarpine, reserpine } \\
\text { Isoproterenol, control }\end{array}$ & 6.12 & 27.87 & 22.70 & 8.77 & 31.13 \\
$\begin{array}{l}\text { Isoproterenol, reser- } \\
\text { pine }\end{array}$ & 6.53 & 30.36 & 24.67 & 8.68 & 29.79 \\
\hline
\end{tabular}

\footnotetext{
' Data expressed as percent of total carbohydrate.
}

compared to that of untreated controls. These observations suggest that, as was previously observed in thê submaxillary salivary gland $(18,19)$, the drug treatment induces a hypersecretory state in the airways, involving an increased release of mucous glycoproteins. It appears, therefore, that the reserpine-treated animal model develops a fairly generalized exocrine gland disturbance, with characteristics that resemble those of CF patients (7). The fact that this disturbance also affects the respiratory tract, a target organ which is prominently involved in CF, makes the animal model a useful tool for the further study of possible pathogenetic mechanisms in CF.

Chronic pulmonary disease, usually severe and progressive, is a prominent feature in $\mathrm{CF}(7)$. The basic pathologic lesion consists of obstruction by mucopurulent material, which accumulates presumably as a result of a hypersecretory state $(6,7)$. The increased secretion and the apparent alteration in the physicochemical properties of pulmonary mucous glycoproteins prompted a number of studies of their composition. Earlier findings suggested an alteration in the fucose to sialic acid ratios in the carbohydrate components of these glycoproteins (22), but these changes were not subsequently confirmed. More recent investigations have also failed to demonstrate a consistent qualitative change in mucous glycoproteins in the respiratory secretions of the CF patient, with the possible exception of a higher percent of sulfated components, as demonstrated by both biochemical $(2,3)$ and histochemical $(12$, 13) techniques. It is significant, therefore, that the results of our experiments indicate no significant difference in the percent distribution of neutral sugars, amino sugars, and sialic acid in the lavage samples of the reserpine-treated animals and of untreated controls, despite a significant increase in the total carbohydrate content of the former.

The mechanism through which chronic reserpine administration may induce an increased secretion of protein and of carbohydrate in the airways is not immediately apparent from the results of the present experiments. The pharmacologic action of this drug is a complex one and involves not only the depletion of norepinephrine from sympathetic nerve terminals (23), but also direct effects on several metabolic functions of target tissues (27). In the salivary glands, reserpine most likely alters membrane function and the utilization of energy (17). It appears, therefore, that its effects on the secretory elements of the respiratory tree may involve more than one metabolic function and further study will be required to elucidate its exact mechanism of action. The physiologic control of mucous glycoprotein synthesis and secretion in the respiratory tract, as well as the source of these secretory products, remain obscure. Available evidence suggests that submucosal mucous glands respond to cholinergic, but not to adrenergic stimulation with an enhanced release of macromolecules (5). Other evidence has indicated, however, that repeated administration of a substituted amine causes a decrease in the synthesis, but an increase in the secretion of guinea pig and human mucous glands and goblet cells (11) and Sturgess and Reid (26) found that both pilocarpine and isoproterenol induced goblet cell hyperplasia in the rat when administered for several days. Our results on the acute effects of these two secretagogues suggest that, in normal rats, stimulation with either pilocarpine or isoproterenol results in a $15 \%$ increase in the organic components of lung lavage samples. These results, on the other hand, do not indicate whether the source of the glycoproteins is the same under both types of stimulation but, on the basis of the observations of Sturgess and Reid (26), the cell that responds to isoproterenol may be a different goblet cell type than that affected by cholinergic stimulation. It is possible, therefore, that the overall secretion in the airways is a mixture of glycoproteins from different cell sources and results from a balance between parasympathetic and sympathetic influences on these sources. By interfering with the sympathetic input through depletion of norepinephrine, reserpine could alter this balanced regulation and enhance the effects of the cholinergic innervation while inhibiting those of $\beta$-adrenergic influences.

In contrast to the enhanced response to pilocarpine, the response to isoproterenol appeared to be somewhat reduced (although not 
significantly) in the reserpine-treated rats. Although chronic reserpine administration has been shown to cause a nonspecific type of supersensitivity in several tissues, such effect is frequently masked by the direct toxic effects of the drug on the effector cells (Fleming et al. (9)). A similar masking of supersensitivity was previously observed in salivary secretions in vivo (Martinez et al. (16)) and the same effect could occur in the cells that respond to isoproterenol stimulation in the airways.

A recent study of the lipids found in lung lavage specimens of CF patients showed that they constitute $30-40 \%$ of the insoluble material and that phosphatidylcholine was the predominant one (25). In the present experiments, chronic reserpine administration was found to decrease the neutral lipid content of lung lavage samples obtained before stimulation, but to increase their phospholipid content. Stimulation with either pilocarpine or isoproterenol, furthermore, caused a slight increase in the phospholipid content of the lavage samples from control rats while it resulted in a decreased phospholipid content of the lavage fluid of reserpinetreated rats. The increase in the phospholipid content of the unstimulated lavage samples of reserpine-treated rats and the different response in phospholipid secretion to stimulation in these animals suggest that reserpine administration interferes with phospholipid metabolism in the lung. There is clear evidence that the source of phospholipids in lung secretions is the type II alveolar cells and a great deal is known about the metabolism of phospholipids in the lung (30). The effect of chronic reserpine administration on lung lipid metabolism could be a complex one and further studies are necessary to determine whether this effect includes changes in the amount of lysophosphatides and free fatty acids and in the degree of saturation of fatty acids, as have been described in lung lavage samples of patients with CF (25).

\section{CONCLUSIONS}

From the observations made in this investigation, we conclude that the chronic administration of reserpine to rats induces a hypersecretory state in the respiratory tract, involving an increased production of mucous glycoproteins and an enhanced secretion of these components in response to stimulation with pilocarpine. This effect also involves the lipids, primarily as the result of changes in phospholipid secretion, but does not seem to be related to qualitative changes in the carbohydrate components of the glycoproteins. Because a hypersecretion of glycoproteins is a prominent feature in the lung of $C F$ patients, these findings suggest that the reserpine-treated animal model will be a useful tool in the further study of possible pathogenetic mechanisms in CF.

\section{REFERENCES AND NOTES}

1. Boas, N. F.: Method for the determination of hexosamines in tissues. J. Biol. Chem., 204: 553 (1953).

2. Boat, T. F., Cheng, P. W., Tyer, R. N., Carlson, D. M. and Polony, I.: Human respiratory tract secretions, mucous glycoproteins of nonpurulent tracheobronchial secretions and sputum of patients with bronchitis and cystic fibrosis. Arch. Biochem. Biophys., 177: 95 (1976).

3. Boat, T. F., Kleinerman, J. I., Carlson, D. M., Maloney, W. H., and Matthew, L. W.: Human respiratory tract secretions. I. Mucous glycoproteins secreted by cultured nasal polyp epithelieum from subjects with allergic rhinitis and with cystic fibrosis. Amer. Rev. Respir. Dis., 110: 428 (1974).

4. Barbero, G. J., and Chernick, W. S.: The role of the autonomic nervous system in cystic fibrosis. In: P. A. DiSant'Agnese, Research on pathogenesis of Cystic Fibrosis. p. 208-221 (National Institutes of Health, Bethesda, 1964).

5. Chakrin, L. W., Baker, A. P., Christian, P. and Wardell, J. R.: Effect of cholinergic stimulation on the release of macromolecules by canine trachea in vitro. Amer. Rev. Resp. Dis., 108: 69 (1963).

6. Chernick, W. S., and Barbero, G. J.: Studies on human tracheobronchial secretions in normal and pathophysiological conditions. Ann. N. Y. Acad. Sci., 106: 698 (1963).
7. DiSant'Agnese, P. A., and Talamo, R. C.: Pathogenesis and physiopathology of cystic fibrosis of the pancreas. N. Engl. J. Med., 277: 1287 (1967).

8. Dubois, M., Gilles, K. A., Rebers, A., and Smith, F.: Colorimetric method for determination of sugars and related substances. Anal. Chem., 28: 350 (1956)

9. Fleming, W. W., McPhillips, J. J., and Westfall, D. P.: Postjunctional supersensitivity and subsensitivity of excitable tissues to drugs. Erg. Physiol., 68: 55 (1973).

10. Huang, T. C., Chen, C. T., Wefler, V.: Axstable reagent for the LiebermannBurchard reaction. Application to rapid serum cholesterol determination. Anal. Chem., 33: 1405 (1961).

11. Janatuinen, M., and Korhonen, L. K.: The effect of a substituted benzylamine (Bisoloon) on mucosubstance production Naunyn. Schmiederberg Arch. Pharmacol. Exptl. Pathol., 265: 112 (1969).

12. Lamb, D., and Reid, L.: The tracheobronchial submucosal glands in cystic fibrosis: a qualitative and quantitative histochemical study. Brit. J. Dis. Chest, 66: 239 (1972)

13. Lev, R., and Spicer, S. S.: A histochemical comparison of human and in hypersecretory states including pancreatic cystic fibrosis. Amer. J. Pathol., 46: 23 (1965).

14. Lowry, O. H., Rosebrough, N. J., Farr, A. L., and Randall, R. J.: Protein measurement with the Folin Phenol reagent. J. Biol. Chem., 193: 265 (1951).

15. Lowry, R. R., and Tinsley, I. J.: A simple, sensitive method for lipid phosphorus. Lipids, 9; 491 (1974).

16. Martinez, J. R., Quissell, D. O., Wood, D. L., and Giles, M.: Abnormal secretory response to parasympathomimetic and sympathomimetic stimulation from the submaxillary gland of rats treated with reserpine. J. Pharmacol. Exptl. Ther., 194: 384 (1975).

17. Martinez, J. R., and Quissell, D. O.: Potassium release from the rat submaxillary gland in vitro. III. Effects of pretreatment with reserpine. J. Pharmacol. Exptl. Ther., 201: 206 (1977).

18. Martinez, J. R., Adelstein, E., Quissell, D. O., and Barbero, G. J.: The chronically reserpinized art as a possible model for cystic fibrosis. I. Submaxillary gland morphology and ultrastructure. Pediatr. Res., 9: 463 (1975).

19. Martinez, J. R., Adshead, P. C., Quissell, D. O., and Barbero, G. J.: The chronically reserpinized rat as a possible model for cystic fibrosis. II. Composition and cilioinhibitory effects of submaxillary saliva. Pediatr. Res., 9: 470 (1975).

20. Perlmutter, J., and Martinez, J. R.: The chronically reserpinized rat as a possible model for cystic fibrosis. VIl. Alterations in the secretory response to cholecystokinin and to secretin from the pancreas in vivo. Pediatr. Res., 12: 188 (1978).

21. Poorthuis, J. H. M., Yazaki, P. J., and Hostetler, K. Y.: An improved two dimensional thin-layer chromatography system for the separation of phosphatidyl glycerol and its derivatives. J. Lipid Res., 17: 433, (1976).

22. Potter, J. I., Matthews, I. W., Lemm, J., and Spector, S.: Human pulmonary secretions in health and disease. Ann. N. Y. Acad. Sci., 106: 692 (1963).

23. Roth, R. H., and Stone, E. A.: The action of reserpine on noradrenergic biosynthesis in sympathetic nerve tissue. Biochem. Pharmacol., 17: 1581 (1968).

24. Rouser, G., Kritchevsky, G., and Yamamoto, A.: Column chromatographic and associated procedures for separation and determination of phosphatides and glycolipids. In: G. G. Marinette: Lipid Chromatographic Analysis Vol. I. p. 272 (Marcel Dekker, Inc. New York 1967).

25. Sahu, S., and Lynn, W. S.: Lipid composition of airway secretions from patients with asthma and patients with cystic fibrosis. Amer. Rev. Respir. Dis., 115: 233 (1977).

26. Sturgess, J., and Reid, L.: The effect of isoprenaline and pilocarpine on (a) bronchial mucus-secreting tissue and (b) pancreas, salivary glands, heart. thymus, liver, and spleen. Brit. J. Exptl. Pathol., 54: 388 (1973).

27. Sun, S. C., Sohal, R. S., Colcolough, H. L., and Burch, G. E.: Histochemical and electron microscopic studies of the effects of reserpine on the heart muscle of mice. J. Pharmacol. Exptl. Ther., 161: 210 (1968).

28. Thompson, F. E., Quissell, D. O., Williams, C. H., and Martinez, J. R.: The chronically reserpinized rat as a possible model for cystic fibrosis. IV. The protein composition of pulmonary lavage fluid. Pediatr. Res., 10: 632 (1976).

29. Tuckley, B., and Storry, J. E.: An improved method for thin layer chromatography of plasma lipids by single development. Lipids, 9: 493 (1974).

30. Van Golde, L. M. G.: Metabolism of phospholipids in the lung. Amer. Rev. Respir. Dis., 114: 977 (1976).

31. Varma, R., Varma, R. S., and Wardi, A. H.: Separation of aldononitrile acetates of neutral sugars by gas-liquid chromatography and its application to polysaccharides. J. Chromatog., 77: 222 (1973).

32. Warren, L.: The thiobarbituric acid assay of sialic acids. J. Biol. Chem., 234: 1971 (1959).

33. The authors thank Linda Garrett for her technical assistance.

34. This research was supported by grant HL19160 from the National Heart, Blood and Lung Institute, National Institutes of Health.

35. Received for publication March 28, 1978.

36. Accepted for publication June $29,1978$. 